УДК 343.98

DOI https://doi.org/10.32844/2618-1258.2019.5-2.43

IKACB A.P.

\title{
ОСОБА ЗЛОЧИНЦЯ ТА ОСОБА ПОТЕРПІЛОГО У СТРУКТУРІ КРИМІНАЛІСТИЧНОЇ ХАРАКТЕРИСТИКИ ВТЯГНЕННЯ НЕПОВНОЛІТНІХ У ЗЛОЧИННУ ДІЯЛЬНІСТЬ
}

Криміналістичне дослідження особи злочинця та особи потерпілого здійснюється головним чином для визначення ознак, які зумовлюють злочинну поведінку та вчинення злочинних дій. Важливим завданням $є$ встановлення взаємозв'язків особи злочинця та особи потерпілого, що впливає на вибір обстановки, способу вчинення злочину та утворюваної слідової картини. При цьому особа злочинця, що втягує неповнолітніх у злочинну діяльність, $\epsilon$ «ключовою» у структурі криміналістичної характеристики злочину. Проведене вивчення кримінальних проваджень дало змогу виокремити ознаки особи злочинця, що втягує неповнолітніх у злочинну діяльність. Зокрема, типовими ознаками є такі: чоловік, 20-33 років, не одружений, офіційно не працевлаштований, має повну середню або середню спеціальну освіту, схильний до вживання алкогольних напоїв, наркотичних засобів, у низці випадків - раніш судимий.

Для криміналістичної характеристики важливо з'ясувати характер взаємозв'язку між особою злочинця та особою потерпілого. Здебільшого вказані особи підтримують знайомство чи товариські відносини, що нерідко виникали під час спільного вживання алкогольних напоїв чи наркотичних засобів.

Істотне значення для характеристики особистості неповнолітніх, втягнених у злочинну діяльність, мають відомості про їхню поведінку в період, що передував вчиненню злочину. Типовою $є$ ситуація, коли підлітки раніше притягувалися до адміністративної, рідше - кримінальної відповідальності. Найбільш вразлива для втягування у злочинну діяльність вікова група неповнолітніх від 14 до 15 років. Нерідко батьки, інші родичі, причетні до втягнення неповнолітнього до злочинної діяльності. Варто зазначити, що з особою злочинця та особою потерпілого під втягнення в злочинну діяльність тісно пов'язаний такий елемент криміналістичної характеристики злочину, як обстановка вчинення злочину.

Усебічне дослідження особи злочинця та потерпілого, їх поведінки, стосунків між ними має принципове значення для встановлення обставин кримінального провадження під час розслідування втягнення неповнолітніх у злочинну діяльність.

Ключові слова: розслідування, злочин, кримінальне провадження, взаємозв'язок, підліток.

Forensic investigation of the perpetrator's identity and the victim's identity is performed primarily to identify the characteristics that lead to criminal behavior and the commission of criminal acts against a minor victim. An important task is to establish the relationship between the offender and the minor victim, which influences the choice of the situation, the method of the crime and the resulting picture. At the same time, the identity of the offender, who involves the minors in the criminal activity, is "key" in the structure of the forensic characteristic of the crime. The conducted investigation of criminal proceedings made it possible to distinguish the characteristics of the perpetrator's personality, which involves minors in criminal activity. In particular, typical features are:

(C) ІКАЄВ А.Р. - викладач циклу спеціальних дисциплін (Київський центр первинної професійної підготовки «Академія поліції» Національної академії внутрішніх справ) 
a man, 20-33 years old, unmarried, not formally employed, with complete secondary or secondary specialized education. Prone to alcohol, drugs, in some cases previously convicted.

For forensic characteristics, it is important to find out the nature of the relationship between the offender and the victim. In most cases, these individuals support dating or social relationships that often occur when alcohol or drugs are shared.

Information on their behavior in the period preceding the commission of the crime is essential for the characterization of the personality of minors involved in criminal activity. Typical is a situation where adolescents have previously been held to administrative, and rarely criminal liability. The age group of minors aged 14 to 15 is most vulnerable to involvement in criminal activity. Often parents, other relatives are involved in the involvement of a minor in criminal activity. With person of the criminal and person of the victim is closely related such an element of the criminalistics characteristics crime as situation commission of crime.

Comprehensive investigation of the perpetrator's identity and the victim, their behavior, and the relationship between them is of paramount importance for establishing the circumstances of criminal proceedings in the investigation of the involvement of minors in criminal activity.

Key words: investigation, crime, criminal proceedings, interconnection, teenager.

Вступ. Суспільне життя впливає на стан злочинності неповнолітніх, способи, форми та методи їх злочинної діяльності. Стан злочинності неповнолітніх викликає занепокоєння суспільства, державних органів та громадських організацій, вимагає застосування правоохоронними органами рішучих заходів протидії. Однак суспільна небезпека злочину, передбаченого ст. 304 КК України, заслуговує на особливу увагу, адже передбачає втягнення неповнолітніх у злочинну діяльність, пияцтво, заняття жебрацтвом, азартними іграми. За наявних умов важливо розробити методику розслідування втягнення неповнолітніх у злочинну діяльність, важливою складовою частиною котрої є криміналістична характеристика цього злочину.

Теоретичне підгрунтя дослідження становлять фундаментальні праці, в яких висвітлено концептуальні засади методики розслідування злочинів, зокрема наукові доробки Л.I. Аркуші, А.Ф. Волобуєва, В.А. Журавля, В.О. Коновалової, В.В. Тіщенка, Л.Д. Удалової, П.В. Цимбала, С.С. Чернявського, Ю.М. Чорноус, В.Ю. Шепітька, Б.В. Щура. Методика розслідування втягнення неповнолітніх у зайняття жебрацтвом не була предметом окремого монографічного дослідження. Особливості кримінального провадження в справах про злочини неповнолітніх досліджувалися в дисертації М.О. Карпенко (Київ, 2004), а методика розслідування втягнення неповнолітнього в зайняття жебрацтвом - у дисертації А.І. Довгань (Львів, 2019).

Постановка завдання. Метою статті є дослідження особи злочинця та особи потерпілого у структурі криміналістичної характеристики втягнення неповнолітніх у злочинну діяльність. Завданнями статті $є$ виокремлення ознак особи злочинця та особи потерпілого у структурі криміналістичної характеристики втягнення неповнолітніх у злочинну діяльність, визначення їх взаємозв'язків, формування криміналістичних рекомендацій із метою підвищення ефективності розслідування цього злочину.

Результати дослідження. Попри дослідження механізму втягнення неповнолітніх у злочинну діяльність вченими із різних галузей наукового знання, проблема не втрачає свої гостроти. За цих умов формування ознак особи злочинця та особи потерпілого як складової частини криміналістичної характеристики дасть змогу підвищити ефективність діяльності із виявлення, розслідування та запобігання втягнення неповнолітніх у злочинну діяльність.

Взагалі за основу варто прийняти думку, що структура методики розслідування окремого виду (групи) злочинів може бути визначена відповідно до таких елементів: криміналістична характеристика злочину; обставини, що підлягають з'ясуванню; особливості початкового етапу розслідування; типові ситуації й дії слідчого на початковому етапі розслідування; наступний етап розслідування і тактика окремих процесуальних, слідчих (розшукових), негласних слідчих (розшукових) дій; профілактична діяльність слідчого при розслідуванні злочину [1, с. 404].

Криміналістична характеристика - це система відомостей про елементи механізму вчинення злочинів окремого виду (групи), в яких відображаються закономірні зв'язки між цими елементами, використовувані для побудови й перевірки версій під час розслідування конкретних злочинів (О.М. Колесніченко, В.О. Коновалова). Однак теоретичне осмислення криміналістич- 
ної характеристики злочину може відбуватись у значенні як системи ознак конкретного злочину (М.О. Селіванов, Б.К. Гавло, А.А. Фокін), так і наукової категорії, що дає змогу прогнозувати ймовірне вчинення повторного злочину чи серійних злочинів певної категорії (В.А. Журавель) $[2$, c. 31$]$.

Особа злочинця як елемент криміналістичної характеристики традиційно привертає увагу вчених, які наголошують на взаємозв'язку та взаємозалежності елементів криміналістичної характеристики злочину. Особливого значення це набуває під час вивчення злочинця та встановлення його взаємозв'язку із потерпілим. Вказані елементи криміналістичної характеристики злочину перебувають у взаємозв'язку, що проявляється як на теоретичному, так й на емпіричному рівнях.

Дослідження особистості людини - одна з найскладніших проблем філософії, антропології, психології та інших наук гуманітарного напряму. Проблему особи необхідно розглядати крізь призму її внутрішньої структури, організації та функціонування іiї психічних процесів. Ї̈̈ може бути представлено як систему, що охоплює тілесні, психічні й атрибутивні властивості [3, с. 94].

Криміналістичне дослідження особи злочинця здійснюється головним чином для виявлення й оцінки тих ознак, які зумовлюють злочинну поведінку. Також важливим завданням $\epsilon$ встановлення взаємозв'язків особи злочинця та особи неповнолітнього потерпілого, способу вчинення злочину та механізму злочинного втягнення, способу, обстановки вчинення злочину та слідової картини та ін.

На думку О.М. Коршунової та О.О. Степанова, злочини вчиняють конкретні особи, які мають певну сукупність ознак, що характеризують їх в особистісному контексті й слугують основою для їх визначення як суб'єктів посягання. Останній є елементом складу злочину, конкретною особою, яка фактично вчинила суспільно небезпечне діяння, ключовою фігурою в системі посягання. Від нього залежить склад злочину. Ця особа $\epsilon$ «продуктом» суспільства, середовища, в якому вона зросла, живе та працює. Їй притаманні розум, воля, емоції, знання, потреби й навички, що визначають ставлення до дійсності, власної поведінки та вчинення злочинного посягання [4, с. 63$]$.

Аналіз наукових джерел переконує, що такий елемент, як особа злочинця, $є$ предметом вивчення майже кожного науковця, який розглядає криміналістичну методику, зокрема криміналістичну характеристику злочинів. Проте це не означає, що питання про ознаки та властивості особи злочинця остаточно вирішено. Як уже було зазначено, її здебільшого характеризують у кримінологічному, психологічному та кримінально-правовому аспектах.

Особа злочинця, як і будь-якої іншої людини, має безліч різноманітних ознак: соціальні зв'язки (політичні, трудові, побутові, сімейні тощо); морально-політичні якості (світогляд, спрямованість, переконання, інтереси); психологічні властивості й особливості (інтелект, вольові якості, емоційні особливості, темперамент); демографічні та фізичні дані (стать, вік, стан здоров'я, біографія, життєвий досвід, освіта тощо).

Поняття «особа злочинця» тлумачиться як сукупність істотних і стійких соціальних ознак та соціально зумовлених біопсихологічних особливостей індивіда, які, об'єктивно реалізуючись у вчиненому конкретному злочині (злочинах) за вирішального впливу негативних обставин зовнішнього середовища, наділяють учинене діяння характером суспільної небезпеки, а винну особу (цього індивіда) - властивостями суспільної небезпеки, у зв'язку з чим її притягують до відповідальності, передбаченої кримінальним законом [5, с. 119].

Розробляючи методи вивчення особи злочинця, учені не обмежуються кримінально-правовими чи соціологічними дослідженнями. Тут ураховують також психологічні, педагогічні й інші знання, які допомагають визначити мотиви та мету вчинення злочину, а також засоби впливу на особу злочинця.

Проведене вивчення кримінальних проваджень дало змогу виокремити ознаки особи злочинця за умови втягнення неповнолітніх у злочинну діяльність. Це чоловік $(80,7 \%), 20-33$ років $(40,9 \%)$, не одружений $(38,6 \%)$, офіційно не працевлаштований $(45,5 \%)$, має повну середню $(28,4 \%)$ або середню спеціальну освіту $(26,2 \%)$. Схильний до вживання алкогольних напоїв, наркотичних засобів $(86,9 \%)$. Неповнолітні часто втягуються у злочинну діяльність раніше судимими особами $(33,3 \%)$.

Особа злочинця у справах про втягнення неповнолітніх у злочинну діяльність може бути класифікована відповідно до певних груп.

По-перше, це особа-втягувач до злочинної діяльності. Це групу становлять молоді люди віком 18-25 років, які групують навколо себе підлітків переважно для дрібних доручень, спільного проведення часу, розпивання спиртних напоїв, вживання наркотиків, вчинення корисливих злочинів, таких як крадіжки, хуліганство. 
По-друге, це втягувачі-рецидивісти - раніше судимі особи старше 25 років. Відбувши покарання, вони намагаються встановити втрачені соціальні зв'язки, і найкраще це виходить із неповнолітніми. Часом у безпечному на вигляд спілкуванні з неповнолітніми втягувачі готують їх до майбутніх спільних злочинів, які, на відміну від тих, про які йшлося в попередньому пункті, вчиняються більш професіонально і часто не відразу розкриваються працівниками поліції, що дає змогу неодноразового вчинення злочинів разом із неповнолітніми. Вчинювані злочини мають в основному корисливо-насильницький характер.

По-третє, втягувачі - організатори злочинних груп. Ці особи часто є вихідцями з категорії раніше судимих, в яких уже усталилися антигромадські погляди. Неповнолітніх вони використовують як засіб для вчинення тяжких злочинів, головним чином розбійних нападів, убивств.

По-четверте, втягувачі-утриманці - родичі (найчастіше батьки) неповнолітніх - деградовані особи, що живуть переважно за рахунок антигромадських занять підлітків. Причому якщо у вчинення злочину неповнолітніх втягують в основному особи чоловічої статі, то в заняття жебрацтвом - здебільшого матері [6, с. 77-78].

Особа потерпілого - досить складна у криміналістичному відношенні фігура. Вона змінює своє становище залежно від категорії злочину, виду злочинного посягання, наявності або відсутності зв'язків між потерпілим і злочинцем, психологічних особливостей потерпілого, його рольових функцій до і під час учинення злочину [7, с. 32]. Саме потерпілий нерідко повідомляє перші вихідні дані, фактичні відомості про подію, що відбулася, інколи дуже важливі для організації і проведення подальшого розслідування [8, с. 8].

В.Ю. Шепітько зауважує, що одним із напрямів криміналістичного вивчення особи потерпілого $є$ побудова та використання криміналістичних характеристик різних видів (категорій) злочинів. Вивчення особи потерпілого має включати в себе: 1) відомості анкетного характеру; 2) соціально-психологічні дані; 3 ) особливості поведінки - до злочинної події, в момент вчинення злочину, після його вчинення; 4) незалежні характеристики (за місцем роботи чи навчання, за місцем проживання, за показаннями рідних, близьких чи найближчого оточення); 5) соціальні зв'язки; 6) дані про суспільно корисну діяльність, їі особливості; 7) матеріальне становище; 8) злочинний досвід; 9) причини віктимної поведінки [9, с. 164-165].

На думку O.І. Резнікової, особа жертви злочину (потерпілого) у криміналістиці - це самостійний елемент криміналістичної характеристики злочинів, який містить систему даних про жертву злочину (потерпілого) від певного виду (групи) злочинних посягань і пов'язаний кореляційними внутрішніми та зовнішніми зв'язкам щодо такої системи. Виокремлення особи жертви злочину (потерпілого) як елемента криміналістичної характеристики злочинів дає змогу на статистичному рівні встановити і проаналізувати зв'язки, з одного боку, між злочинцем і жертвою злочину, а з іншого - між потерпілим та іншими елементами злочинної події та криміналістичної характеристики злочинів [10, с. 10].

I.В. Борисенко виокремлює дві групи особливостей, що впливають на віктимність потерпілого та його взаємозв'язок з іншими елементами криміналістичної характеристики злочину. До першої групи автор включає основні властивості безпосередньо потерпілих, що мають криміналістичне значення: їхній вік і пов'язані з ним особливості психіки, сімейний стан, рід занять, інтелектуальний і фізичний розвиток, а також наявність окремих психічних і фізичних недоліків. До другої групи належать особливості, притаманні поведінці потерпілих, криміналістично значущими з-поміж яких є спосіб життя, коло і характер зв'язків, поведінка в побуті, статева культура, зловживання алкоголем та інші особливості, що характеризують їхню поведінку поза зв'язком з учиненими щодо них злочинами [11, с. 142].

Для криміналістичної характеристики важливо з'ясувати характер взаємозв'язку між особою злочинця та особою потерпілого. Так, здебільшого $(54,2 \%)$ вказані особи підтримували знайомство чи товариські відносини, у 45,8\% випадків знайомство було короткочасним $\mathrm{i}$, як правило, відбувалося під час спільного вживання алкогольних напоїв чи наркотичних засобів. Віковий склад неповнолітніх, втягнених у злочинну діяльність, був таким: $7-13$ років $-29,3 \%$; $14-15$ років - $50,0 \% ; 16-17$ років $-20,7 \%$.

Варто враховувати, що злочинці, втягуючи неповнолітніх до злочинної діяльності, розраховують, що діти у віці до 13 років, згідно з Кримінальним кодексом України, вважаються такими, що не досягли віку кримінальної відповідальності. Тому вони можуть використовуватися дорослими співучасниками 3 метою забезпечення підготовки, безпосереднього вчинення злочину та приховування його наслідків. Неповнолітні віком до 15 років, як правило, вчиняють крадіжки, угони транспортних засобів, а насильницькі злочини скоюють в основному підлітки старшого віку - 16-17 років, котрі вже більш розвинені фізично. 
Типовий склад сім’ї як особи злочинця, так і потерпілого, значною мірою схожий: біля $70,3 \%$ із них виховувалися в неповних сім'ях, здебільшого однією матір'ю, де застосовувалися непедагогічні методи виховання. Поведінка таких підлітків здебільшого не контролюється, і саме вони частіше за інших підпадають під вплив дорослих правопорушників. Невисокий освітній і культурний рівень підлітків, а також недоліки виховної роботи як удома, так і за місцем навчання, провокують недоліки інтелектуального, морального та психологічного розвитку особистості.

Також підліткам властиві неврівноваженість, імпульсивність, безвідповідальність, низький рівень самодисципліни. У цих підлітків вузький кругозір, бідний словниковий запас, вони не вміють чітко висловлювати свої думки, характеризуються низьким рівнем знань, браком елементів культури, затримкою інтелектуального розвитку.

Істотне значення для характеристики особистості неповнолітніх, втягнених у злочинну діяльність, мають відомості про їхню поведінку в період, що передував вчиненню злочину. Типовою $є$ ситуація, коли підлітки раніше притягувалися до адміністративної $(15,6 \%)$ або кримінальної відповідальності $(11,4 \%)$.

Неповнолітній потерпілий, щодо якого відбувається втягнення в злочинну діяльність, прагне фінансової самостійності, цікавиться сучасними гаджетами, одягом. Отримані дані демонструють, що цей прошарок неповнолітніх вчиняє переважно крадіжки та грабежі $(52,8 \%)$, із числа ж втягнених у злочинну діяльність більший відсоток належить втягненню неповнолітніх у жебрацтво - 40,7\%. Однак все ж більшу кількість неповнолітніх втягують саме з метою їх використання під час вчинення злочинів. Нерідко $(30,1 \%)$ саме батьки, інші родичі причетні до втягнення неповнолітнього до злочинної діяльності.

Варто зазначити, що з особою злочинця та особою потерпілого під втягнення у злочинну діяльність тісно пов'язаний такий елемент криміналістичної характеристики злочину, як обстановка вчинення злочину.

Негативно впливає зниження ролі морально-етичних цінностей у суспільстві, поширення алкоголізму та наркоманії, бажання легкої наживи, матеріальні проблеми, несприятлива обстановка в сім'ї. Якщо сім'я є неблагополучною, підлітки намагаються якомога менше бути вдома, в нездоровій сімейній обстановці й потрапляють під негативний вплив старших осіб, у тому числі раніше судимих.

Чинниками, які провокують зайняття неповнолітніх бродяжництвом, є систематичне домашнє насильство в сім'ї, зловживання членами сім'ї алкогольними напоями, вживання наркотиків та ін. Негативно впливає на стан злочинності неповнолітніх загрозливе поширення наркоманії, вживання психотропних, токсичних речовин, які вживаються спершу із цікавості, бажання змінити реальність, а потім такі випадки відбуваються систематично. Вказана вище проблема, втягнення неповнолітніх до алкоголізму і наркоманії, провокує підбурювання з боку осіб, які ведуть антигромадський спосіб життя, були раніше судимі. Раніш судимі особи, які не стали не шлях виправлення і продовжують займатися злочинною діяльністю, в цій ситуації становлять підвищену небезпеку, адже виступають у ролі «організаторів», створюють біля себе групу підлітків, яких періодично заохочують, дають певні доручення, готують до вчинення злочинів.

Важливе значення має формування належного колективу неповнолітніх у школі, інших закладах освіти. Негативно впливає на провокування втягненню неповнолітніх до злочинної діяльності таке нове протиправне явище, як булінг. Згідно з ч. 1 ст. 173-4 Кодексу про адміністративні правопорушення, булінгом (цькуванням) $є$ діяння учасників освітнього процесу, які полягають у психологічному, фізичному, економічному, сексуальному насильстві, у тому числі із застосуванням засобів електронних комунікацій, що вчиняються стосовно малолітньої чи неповнолітньої особи або такою особою стосовно інших учасників освітнього процесу, внаслідок чого могла бути чи була заподіяна шкода психічному або фізичному здоров'ю потерпілого. Не вдаючись до детальної проблематики булінгу в Україні, зауважимо, що запобігання цього негативного соціального явища і правопорушення вливає на профілактику втягнення неповнолітніх у злочинну діяльність.

Висновки. Усебічне дослідження особи злочинця та потерпілого, їх поведінки, стосунків між ними має принципове значення для встановлення обставин кримінального провадження під час розслідування втягнення неповнолітніх у злочинну діяльність.

Список використаних джерел:

1. Чорноус Ю.М. Криміналістичне забезпечення розслідування злочинів : монографія. Вінниця : Нілан-ЛТД, 2017. 492 с. 
2. Криміналістика : підручник / В.Д. Берназ, В.В. Бірюков, А.Ф. Волобуєв ; за заг. ред. А.Ф. Волобуєва; МВС України. Харків : ХНУВС, 2011. 666 с.

3. Жерж Н.А. Особа злочинця як об’єкт криміналістичного та кримінально-правового вивчення: порівняльно-правовий аналіз. Роль права та закону в громадянському суспільстві : збірник тез наук. доп. Міжнар. наук.-практ. конф., 13-14 лют. 2015 р. Київ, 2015. С. 94-97.

4. Курс криминалистики : в 3 т. / под ред. О.Н. Коршунова, А.А. Степанова. Санкт-Петербург : Юрид. центр Пресс, 2004. Т. 1 : Общетеоретические вопросы. Криминалистическая техника. Криминалистическая тактика. 683 с.

5. Даньшин И.Н. К вопросу о понятии личности преступника. Проблемы социалистической законности. 1980. Вып. 6. С. 117-126.

6. Топольскова I.О. Кримінально-правові та кримінологічні аспекти боротьби з втягненням неповнолітніх у злочинну або іншу антигромадську діяльність : дис. ... канд. юрид. наук : 12.00.08. Луганськ, 2003. 184 с.

7. Коновалова В.Е. Убийство: искусство расследования : [моногр.] Харьков : Факт, $2001.311 \mathrm{c}$. 1988. $160 \mathrm{c}$.

8. Центров Е.Е. Криминалистическое учение о потерпевшем. Москва : Моск. ун-т,

9. Шепітько В.Ю. Особа потерпілого в системі криміналістичної характеристики злочинів. Проблеми законності : респ. міжвідом. наук. збірник / відп. ред. В.Я. Тацій. Харків, 2008. Вип. 93. С. 168-174.

10. Резнікова О.І. Віктимологічне пізнання особи у криміналістиці : автореф. дис. ... канд. юрид. наук : 12.00.09. Харків, 2015. 20 с.

11. Борисенко І.В. Особа потерпілого як елемент криміналістичної характеристики вбивств із розчленуванням трупа. Вісник Харківського національного університету внутрішніх справ. 2006. Вип. 35. С. 142-149.

УДК 343.133

DOI https://doi.org/10.32844/2618-1258.2019.5-2.44

ІЩЕНКО Ю.А.

\section{РЕАЛІЗАЦІЯ ПІДОЗРЮВАНИМ ПРАВА НА УЧАСТЬ У ПРОВЕДЕННІ ПРОЦЕСУАЛЬНИХ ДІЙ}

Під правовим статусом будь-якого учасника кримінального провадження в сучасному кримінальному процесі прийнято розуміти визначену процесуальним законом сукупність прав та обов'язків певної особи. У цьому контексті конструкція більшості норм, які в КПК України визначають статус підозрюваного, скоріше відповідає доктрині природнього права, якій властива сама наявність в індивідуума сукупності прав, без притаманного позитивному праву механізму їх реалізації та відповідальності за їх порушення. При цьому останні надбання кримінально-процесуальної науки спонукають шукати шляхи, якими права учасників провадження зможуть бути реалізовані, адже саме можливість практичної реалізації особою своïx прав $€$ важливою складовою частиною права на справедливий суд, визначеного ст. 6 Конвенції про захист прав людини і основоположних свобод.

Варто підкреслити, що відсутність механізмів реалізації права підозрюваного брати участь у процесуальних діях та відсутність законодавчо закріпленої відповідальності за порушення зазначених прав призводять до так званої декларативності статусу підозрюваного в цій частині, що може спричинити порушення основоположних свобод та загалом не відповідає завданням кримінального провадження.

(C) ІЩЕНКО Ю.А. - адвокат, аспірант кафедри криміналістики та кримінального процесу (Академія адвокатури України) 